\title{
UPAYA MENINGKATKAN KEDISIPLINAN GURU DALAM MENGAJAR DI KELAS MELALUI PENERAPAN REWARD AND PUNISHMENT DI TK MUTIARA IBU KOTA JAMBI
}

\author{
LASMITA \\ TK MUTIARA IBU Kota Jambi \\ Email: Lasmita67@gmail.com
}

\begin{abstract}
ABSTRAK
Salah satu faktor penting dalam meningkatkan mutu pendidikan di sekolah adalah kedisiplinan guru dalam mengajar. Dalam Penelitian Tindakan Sekolah (PTS) ini, penulis mencoba menerapkan tindakan Reward and Punishment untuk para guru di TK Mutiara Ibu Kota Jambi. Penelitian ini dilaksanakan dalam dua siklus yang meliputi kegiatan (1) Perencanaan, (2) Pelaksanaan, (3) Pengamatan dan (4) Refleksi. Hasil penelitian menunjukkan bahwa penerapan Reward dan Punishment efektif untuk meningkatkan kedisiplinan guru dalam mengajar dikelas. Setelah diadakan penerapan tindakan berupa Reward dan Punishment, guru yang terlambat lebih dari 15 menit adalah 0 , dan guru yang terlambat kurang dari 10 menit sebanyak 18 orang guru.
\end{abstract}

\section{Kata Kunci : Kedisiplinan Guru, Reward, Punishment}

\section{A. PENDAHULUAN}

\section{Latar Belakang Masalah}

Di sebuah lembaga pendidikan, guru merupakan figur sentral. Selain mengajar, guru juga berperan sebagai seorang pendidik. Di dalam Undang-undang Sistem Pendidikan Nasional Nomor 20 tahun 2003 disebutkan bahwa guru merupakan tenaga pendidik yang profesional yang bertugas merencanakan dan melaksanakan proses pembelajaran, menilai hasil pembelajaran serta melakukan bimbingan dan pelatihan. Sedangkan pengajaran merupakan upaya guru dalam mengoperasionalkan kurikulum kepada peserta didik, pengajaran menyangkut komponen tujuan, bahan, metode dan alat pendidikan.

Dimyati mengatakan bahwa "Guru adalah semua orang yang berwenang dan bertanggung jawab terhadap pendidikan murid baik secara individual maupun 
klasikal, baik di sekolah maupun di luar sekolah. Ini berarti bahwa seorang guru minimal harus memiliki dasar-dasar kompetensi sehingga memiliki wewenang dan kemampuan dalam menjalankan tugasnya terutama agar dapat meningkatkan suasana belajar yang kondusif'. ${ }^{1}$

Salah satu kunci keberhasilan guru dalam proses pembelajaran adalah melalui kedisiplinan. Dengan disiplin kerja yang tinggi akan meningkatkan pelaksanaan kegiatan belajar mengajar, menjaga suasana ketertiban kelas dan mengatasi kenakalan siswa. Kedisiplinan guru diartikan sebagai sikap mental yang mengandung kerelaan mematuhi semua ketentuan, peraturan dan norma yang berlaku dalam menunaikan tugas dan tanggung jawab.

Fakta yang terjadi di lapangan, masih banyak prilaku guru yang insdisipliner, seperti; datang terlambat ke sekolah, masih kurangnya disiplin guru dalam kehadiran mengajar dikelas, guru masih sering terlambat masuk kelas, dan masih ada yang tidak mengikuti upacara bendera pada hari senin.

Melihat kenyataan di atas, menurut penulis perlu dilakukan suatu tindakan baru agar permasalahan kedisiplinan guru dapat diatasi. Tindakan yang akan penulis lakukan yaitu melalui reward and punishment dengan judul: Upaya Meningkatkan Kedisiplinan Guru Dalam Mengajar di Kelas Melalui Penerapan Reward And Punishment Di TK Mutiara Ibu Kota Jambi

\section{Rumusan Masalah}

Rumusan masalah dalam penelitian ini adalah: "Apakah penerapan Reward and Punishment dapat meningkatkan kedisiplinan guru dalam mengajar di kelas?"

\footnotetext{
${ }^{1}$ Dimyati dan Mudjiono, Belajar dan Pembelajaran, (Jakarta: PT. Rineka Cipta, 2000), hal. 25.
} 


\section{Tujuan Penelitian}

Tujuan dari penelitian ini adalah ingin mencari alternatif pemecahan masalah sebagai upaya meningkatkan kedisiplinan guru dalam mengajar dikelas melalui penerapan Reward and Punishment.

\section{Manfaat Penelitian}

\section{Bagi Siswa}

Dengan adanya penelitian tindakan sekolah (PTS) ini diharapkan dapat meningkatkan kedisiplinan siswa dalam belajar.

\section{Bagi Guru}

a. Dapat menciptakan kesadaran guru tentang tanggung jawabnya terhadap pelaksanaan tugasnya.

b. Diharapkan dapat menjadi motivasi bagi guru dalam meningkatkan kedisiplinan dalam mengajar.

\section{Bagi Sekolah}

Dapat dijadikan sumbangan pemikiran dalam mewujudkan budaya sekolah yang dapat mendorong keberhasilan dan peningkatan mutu pembelajaran.

\section{B. KAJIAN PUSTAKA}

\section{Konsep Tentang Kedisiplinan}

Keith Davis dalam Mangkunegara² mengemukakan bahwa "Dicipline is management as action to enforce organization standards" (disiplin kerja dapat diartikan sebagai pelaksanaan pedoman organisasi). Disiplin yang baik mencerminkan besarnya rasa tanggung jawab seseorang terhadap tugas-tugas yang diberikan kepadanya.

Menurut E. Mulyasa, disiplin adalah suatu kesadaran tertib di mana orangorang yang berhubungan dalam suatu sistem tunduk pada peraturan-peraturan

\footnotetext{
2 Anwar Prabu Mangkunegara, Perencanaan Dan Pengembangan Sumber Daya Manusia, (Bandung: Rafika Aditama, 2003), hal. 129
} 
yang ada dengan senang hati. ${ }^{3}$ Menurut Siagian disiplin adalah suatu bentuk pelatihan yang berusaha memperbaiki dan membentuk sikap dan perilaku karyawan sehingga para karyawan tersebut secara sukarela bekerja secara kooperatif dengan para karyawan lain serta meningkatkan prestasi kerjanya. ${ }^{4}$

Menurut Hasibuan dalam Barnawi ${ }^{5}$, disiplin kerja adalah kemampuan kerja seseorang untuk secara teratur, tekun, terus-menerus, dan bekerja sesuai dengan aturan-aturan yang berlaku dengan tidak melanggar aturan-aturan yang sudah ditetapkan. Menurut Rasdiyanah disiplin yaitu kepatuhan untuk menghormati dan melaksanakan suatu system yang mengharuskan orang untuk tunduk pada keputusan, perintah atau peraturan yang berlaku. Dengan kata lain, disiplin adalah kepatuhan mentaati peraturan dan ketentuan yang telah ditetapkan. ${ }^{6}$

Dalam ajaran Islam, banyak ayat al-Qur`an dan hadist, yang memerintahkan disiplin dalam arti ketaatan pada peraturan yang telah ditetapkan. Antara lain disebutkan dalam surah an-Nisầ ayat 59:

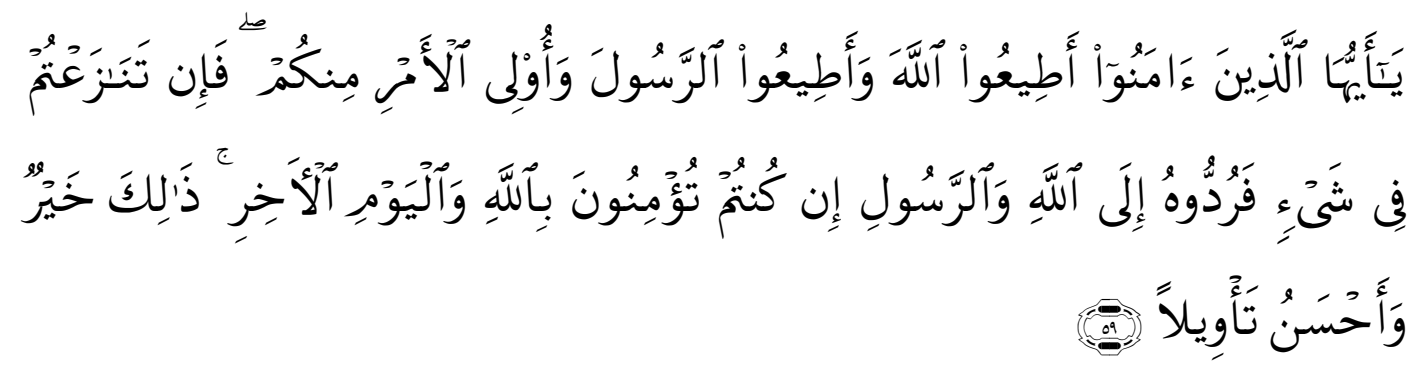

Artinya: Hai orang-orang yang beriman, taatilah Allah dan taatilah Rasul (nya), dan ulil amri di antara kamu. Kemudian jika kamu berlainan pendapat tentang sesuatu, Maka kembalikanlah ia kepada Allah (Al Quran) dan Rasul (sunnahnya), jika kamu benar-benar beriman kepada Allah dan hari kemudian. yang demikian itu lebih utama (bagimu) dan lebih baik akibatnya (Qs. an-Nisâ` [4]: 59).

\footnotetext{
${ }^{3}$ E. Mulyasa, Kurikulum Berbasis Sekolah, (Bandung: Remaja Rosdakarya, 2002), hal. 108

${ }^{4}$ Sondang P. Siagian, Manajemen Sumber Daya Manusia, (Jakarta: PT Bumi Aksara, 2008), hal. 305

${ }_{5}^{5}$ Arifin dan Barnawi, Etika Profesi Kependidikan, (Jogjakarta:Ar-Ruzz Media, 2012), hal. 112

${ }^{6}$ Andi Rasdiyanah, Pendidikan Agama Islam, (Bandung: Lubuh Agung, 1995), hal. 28
} 
Dari ayat di atas terungkap pesan untuk patuh dan taat kepada para pemimpin, dan jika terjadi perselisihan di antara mereka, maka urusannya harus dikembalikan kepada aturan Allah SWT dan Rasul-Nya.

Malayu S.P Hasibuan, ${ }^{7}$ mengemukakan bahwa disiplin yang baik mencerminkan besarnya tanggung jawab seseorang terhadap tugas-tugas yang diberikan kepadanya karena hal ini akan mendorong gairah atau semangat kerja, dan mendorong terwujudnya tujuan organisasi. Sedangkan kedisiplinan adalah kesadaran dan kesediaan seseorang menaati semua peraturan organisasi dan norma-norma sosial yang berlaku. Kesadaran adalah sikap seseorang yang secara sukarela menaati semua peraturan dan sadar akan tugas dan tanggung jawabnya. Jadi, seseorang akan bersedia mematuhi semua peraturan serta melaksanakan tugas-tugasnya, baik secara sukarela maupun karena terpaksa. Kesediaan adalah suatu sikap, tingkah laku, dan perbuatan seseorang yang sesuai dengan peraturan organisasi, baik yang tertulis maupun tidak. ${ }^{8}$

Dari beberapa penjelasan di atas dapat ditarik kesimpulan bahwa disiplin adalah sikap mentaati peraturan dan ketentuan yang telah ditetapkan oleh organisasi baik yang tertulis maupun yang tidak tertulis dengan penuh kesadaran dan tidak mengelak dangan sanksi-sanksi apabila melanggar tugas dan wewenang yang diberikan kepadanya. Dengan kata lain, disiplin adalah sikap menaati peraturan dan ketentuan yang telah ditetapkan tanpa pamrih.

\section{Reward And Punishment}

Reward merupakan sebuah bentuk pengakuan kepada suatu prestasi tertentu yang diberikan dalam bentuk material dan non material yang diberikan oleh pihak organisasi atau lembaga kepada individu atau kelompok pegawai agar mereka dapat bekerja dengan motivasi yang tinggi dan berprestasi dalam mencapai tujuan-tujuan organisasi.

\footnotetext{
7 Malayu S.P Hasibuan, Manajemen Dasar, Pengertian Dan Masalah, (Jakarta: PT Gunung Agung, 1996), hal. 212

${ }^{8}$ Tulus Tu'u, Peran Disiplin Pada Prilaku Dan Prestasi Siswa, (Jakarta: PT. Grasindo, 2004), hal. 63
} 
Besar kecilnya reward yang diberikan kepada yang berhak bergantung kepada banyak hal, terutama ditentukan oleh tingkat pencapaian yang diraih. Selain itu bentuk reward ditentukan pula oleh jenis atau wujud pencapaian yang diraih serta kepada siapa reward tersebut diberikan.

Setiap organisasi menggunakan berbagai reward atau imbalan untuk menarik dan mempertahankan orang dan memotivasi mereka agar mencapai tuiuan pribadi mereka dan tujuan organisasi. Misalnya saja dengan cara memberikan kepada pegawai berupa sertifikat penghargaan, alih tugas, promosi, pujian dan pengakuan dan juga membantu menciptakan iklim yang menghasilkan pekerjaan yang lebih banyak tantangannya dan memuaskan. Sebaliknya, para pegawai menukarkannya dengan waktu, kemampuan, keahlian, dan usaha untuk mendapatkan imbalan yang sesuai. Maksud dari reward yang terpenting bukanlah dari hasil yang dicapai. Melainkan dari hasil yang dicapai tersebut, pemimpin bertujuan untuk membentuk kemauan yang lebih baik dan lebih keras pada pegawainya.

Sedangkan Punishment merupakan proses yang memperlemah atau menekan perilaku. Sedangkan ahmadi dan uhbiyati dalam bukunya menyebutkan bahwa: Punishment (hukuman) adalah suatu perbuatan, di mana kita secara sadar dan sengaja menjatuhkan nestapa kepada orang lain, baik dari segi kejasmanian maupun dari segi kerohanian'. Menurut Mangkunegara, punishment adalah ancaman yang bertujuan unstuck memperbaiki karyawan pelanggar, memelihara peraturan yang berlaku dan memberikan pelajaran kepada pelanggar.

Dari pendapat tersebut dapat disimpulkan bahwa punishment adalah bentuk perbuatan yang tidak menyenangkan bagi guru atas perbuatan yang dianggap melanggar ketentuan yang berlaku dengan tujuan agar ia tidak lagi melakukan hal yang sama.

Menurut pandangan islam, hukuman adalah sebagai tuntunan dan perbaikan bukan sebagai hardikan/balas dendam. Di samping itu, hukuman dapat menginsyafkan pelaku. Adapun jenis-jenis punishment adalah sebagai berikut:

${ }^{9}$ Abu Ahmadi dan Uhbiyati, Ilmu Pendidikan, (Jakarta: Rineka Cipta, 1991), hal. 150 
1. Hukuman ringan, yaitu dengan memberikan teguran lisan maupun teguran secara tertulis kepada karyawan yang bersangkutan.

2. Hukuman sedang, yaitu dengan menunda kenaikan haji yang sebelumnya telah direncanakan.

3. Hukuman berat, yaitu dengan menurunkan pangkat atau demosi, pembebasan dari jabatan, atau dengan pemberhentian kerja.

\section{METODE PENELITIAN}

\section{Jenis Penelitian}

Jenis penelitian yang penulis gunakan adalah Penelitian Tindakan Sekolah (PTS). Penelitian tindakan sekolah merupakan “(1) penelitian partisipatoris yang menekankan pada tindakan dan refleksi berdasarkan pertimbangan rasional dan logis untuk melakukan perbaikan terhadap suatu kondisi nyata; (2) memperdalam pemahaman terhadap tindakan yang dilakukan; dan (3) memperbaiki situasi dan kondisi sekolah/pembelajaran secara praktis"10

Secara singkat, penelitian tindakan sekolah (PTS) bertujuan untuk mencari pemecahan permasalahan nyata yang terjadi di sekolah-sekolah, sekaligus mencari jawaban ilmiah bagaimana masalah-masalah tersebut bisa dipecahkan melalui suatu tindakan perbaikan.

Sedangkan pendekatan yang digunakan dalam penelitian tindakan ini ialah pendekatan kualitatif. Artinya, penelitian ini dilakukan karena ditemukan permasalahan rendahnya tingkat kedisiplinan guru dalam kehadiran dikelas pada proses kegiatan belajar mengajar. Permasalahan ini ditindaklanjuti dengan cara menerapkan sebuah model pembinaan kepada guru berupa penerapan Reward dan Punishment yang dilakukan oleh kepala sekolah, kegiatan tersebut diamati kemudian dianalisis dan direfleksi. Hasil revisi kemudian diterapkan kembali pada siklus-siklus berikutnya.

\footnotetext{
${ }^{10}$ Depdiknas, 2008, hal. 11-12
} 


\section{Setting Penelitian}

Penelitian ini dilakukan di TK Mutiara Ibu Kota Jambi yang beralamatkan di Jl. Kesehatan Jiwa RT 13 No 27 Kel. Kenali Besar Kec. Alam Barajo kota Jambi. Penelitian ini dilaksanakan pada semester ganjil tahun ajaran 2017/2018 pada bulan September-Oktober 2017.

\section{Subjek Penelitian}

Yang menjadi subjek Penelitian Tindakan Sekolah (PTS) ini adalah guruguru yang ada di TK Mutiara Ibu kota Jambi.

\section{Teknik Pengumpulan Data}

Teknik pengumpulan data yang penulis gunakan adalah:

\section{a. Observasi/Pengamatan}

Observasi atau pengamatan dalam penelitian ini diartikan sebagai pengamatan dengan menggunakan indera penglihatan, yang dalam hal ini berarti pengamatan yang tidak mengajukan pertanyaan-pertanyaan. Observasi dilakukan untuk mengamati dan membuat catatan deskriptif secara selektif terhadap latar belakang dan semua kegiatan yang dilakukan pada pengelolaan taman kanakkanak.

Peneliti menggunakan teknik observasi karena peneliti dapat mengetahui secara langsung segala yang terjadi di lapangan. Instrumen yang digunakan selama pengamatan adalah lembar pengamatan yang berisi kisi-kisi pengamatan agar pencatatan pengamatan lebih sistematis. Dalam penelitian ini akan dilakukan pengamatan terhadap kedisiplinan guru dengan memberikan reward dan punishment.

\section{b. Wawancara}

Wawancara adalah bentuk observasi antara dua orang, melibatkan seseorang yang ingin memperoleh informasi dan seorang lainnya dengan mengajukan pertanyaan-pertanyaan berdasarkan tujuan tertentu. Wawancara 
secara garis besar dibagi menjadi dua, yaitu wawancara tidak terstruktur (wawancara terbuka) dan wawancara terstruktur (wawancara baku).

Dalam penelitian ini, peneliti menggunakan teknik wawancara karena dapat memperoleh informasi dari informan sebanyak mungkin secara detail dan dapat bertatap muka secara langsung. Peneliti melakukan wawancara secara tak terstruktur pada subjek penelitian yaitu kepala sekolah taman kanak-kanak, pengelola, dan guru/tutor. Subjek penelitian diberikan kebebasan dalam menjawabnya.

\section{c. Dokumentasi}

Dokumentasi merupakan teknik pengumpulan data dengan menggunakan teknik tertulis. Akhir-akhir ini orang juga menggunakan record dalam pengumpulan data. Guba dan Lincoln mendefinisikan record sebagai pernyataan tertulis yang disusun oleh seseorang atau lembaga untuk keperluan pengujian suatu peristiwa atau penyajian akunting.

Peneliti mendokumentasikan sesuatu yang diperlukan dalam penelitian ini di Taman kanak-kanak Mutiara Ibu Kota Jambi.

\section{HASIL PENELITIAN DAN PEMBAHASAN}

\section{1) Siklus 1}

Siklus 1 terdiri atas beberapa tahap, yaitu : (1) Perencanaan, (2) Pelaksanaan, (3) Pengamatan dan Evaluasi, dan (4) Refleksi.

\section{Perencanaan}

Perencanaan adalah langkah awal yang dilakukan oleh penulis saat akan memulai tindakan. Adapun kegiatan perencanaan adalah sebagai berikut:

(a) Merumuskan masalah yang akan dicari solusinya.

Dalam penelitian ini masalah yang akan dicari solusinya adalah masih banyaknya guru yang kurang disiplin dalam kehadiran dan dalam proses belajar mengajar. 
(b) Merumuskan tujuan penyelesaian masalah/tujuan menghadapi tantangan/tujuan melakukan inovasi/tindakan.

Dalam penelitian ini penulis mengambil rencana untuk melakukan tindakan memberikan Reward dan Punishment kepada guru-guru untuk meningkatkan kedisiplinan guru dalam kehadiran dikelas pada proses belajar mengajar.

(c) Merumuskan indikator keberhasilan penerapan Reward dan Punishment dalam meningkatkan disiplin guru dalam kehadiran dikelas pada proses belajar mengajar. Indikator keberhasilan penerapan tindakan ini penulis tetapkan sebesar $75 \%$, artinya tindakan ini dinyatakan berhasil bila $75 \%$ guru tidak terlambat masuk kelas dalam proses pembelajaran.

(d) Merumuskan langkah-langkah kegiatan penyelesaian masalah/kegiatan menghadapi tantangan/kegiatan melakukan tindakan. Langkah-langkah yang diambil penulis dalam melakukan tindakan antara lain adalah melakukan sosialisasi kepada para guru mengenai penelitian yang akan dilaksanakan, serta menyampaikan tujuan dari penerapan tindakan yang dilakukan oleh penulis. Kepada para guru disampaikan mengenai penerapan Reward dan Punishment yang akan diterapkan dalam penelitian ini. Pada siklus pertama ini, akan dipampang/ditempel diruang guru, maupun diruang TU, peringkat nama-nama guru yang paling rendah tingkat keterlambatan masuk kelasnya sampai yang paling tinggi tingkat keterlambatannya.

(e) Mengidentifikasi warga sekolah dan atau pihak-pihak terkait lainnya yang terlibat dalam penyelesaian masalah/menghadapi tantangan/melakukan tindakan. Penulis melakukan identifikasi siapa saja yang dilibatkan dalam penelitian ini. Pihak-pihak yang dilibatkan dalam penelitian ini adalah : guru, guru piket, TU, dan siswa.

(f) Mengidentifikasi metode pengumpulan data yang akan digunakan. Metode pengumpulan data yang diambil oleh penulis merupakan data kualitatif melalui observasi, pengamatan serta wawancara kepada siswa mengenai kehadiran guru dikelas pada kegiatan belajar mengajar.

(g) Penyusunan instrumen pengamatan dan evaluasi. Dalam pengambilan data, penulis menggunakan instrument berupa lembar observasi/pengamatan, skala 
penilaian serta angket yang disebarkan kepada siswa, untuk mengetahui penilaian dari siswa mengenai tingkat kehadiran guru dikelas dalam proses kegiatan belajar mengajar.

(h) Mengidenifikasi fasilitas yang diperlukan.

Fasilitas atau alat bantu yang digunakan dalam penelitian ini antara lain : kertas (lembar pengamatan), alat tulis berupa balpoin, serta jam dinding yang ada disetiap kelas, serta rekap jumlah kehadiran dari setiap guru.

\section{Pelaksanaan}

Pelaksanaan penelitian tindakan sekolah ini dilaksanakan melalui beberapa kegiatan, antara lain:

(a) Menyebarkan lembar pengamatan kepada setiap ketua kelas atau sekretaris kelas sebanyak 12 set, sesuai dengan banyaknya jumlah rombongan belajar di TK Mutiara Ibu sebanyak 12 rombongan belajar. Dalam lembar pengamatan itu, telah dibuat daftar guru yang mengajar dikelas itu setiap jam dan diberi kolom jam masuk kelas serta jam keluar kelas.

(b) Berkoordinasi dengan petugas piket yang setiap hari terdiri dari 2 orang petugas, yaitu dari guru yang tidak mempunyai jam mengajar pada hari itu dan satu orang dari tata usaha. Petugas piket akan mengedarkan daftar hadir guru dikelas yang telah dibuat agar dapat melihat tingkat kehadiran guru disetiap kelas dan disetiap pergantian jam pelajaran. Guru yang terlambat lebih dari 15 menit, dianggap tidak hadir dan diberi tanda silang.

(c) Setelah selesai jam pelajaran, dilakukan rekapitulasi dari hasil pengamatan, baik dari guru piket, dari siswa maupun dari penulis.

(d) Kegiatan tersebut dilakukan terus setiap hari kepada setiap guru selama satu minggu (satu siklus).

\section{Pengamatan dan Evaluasi}

Pengamatan atau observasi dilakukan oleh peneliti dengan menggunakan lembar observasi selama satu minggu (satu siklus), untuk semua guru yang 
berjumlah 23 orang. Selama pengamatan peneliti dibantu atau berkolaborasi dengan guru piket.

Pengamatan oleh peneliti meliputi :

(a) Kehadiran guru dikelas

(b) Tingkat keterlambatan guru masuk kelas

(c) Waktu meninggalkan kelas setelah selesai pelajaran

Peneliti juga melakukan penilaian dari hasil lembar observasi yang dibagikan kepada pengurus kelas untuk mengamati kehadiran guru dikelas. Dari hasil pengamatan serta rekap dari tingkat kehadiran guru dikelas pada proses belajar mengajar dapat dilihat pada tabel berikut:

REKAPITULASI TINGKAT KETERLAMBATAN GURU DI KELAS SIKLUS 1

\begin{tabular}{|c|c|c|}
\hline \multicolumn{3}{|c|}{ Waktu keterlambatan/jumlah/prosentase } \\
\hline Kurang dari 10 menit & 10 menit s.d 15 menit & Lebih dari 15 menit \\
\hline 5 & 7 & 11 \\
\hline $21,74 \%$ & $30,43 \%$ & $47,83 \%$ \\
\hline
\end{tabular}

Dari hasil rekapitulasi tingkat keterlambatan guru dikelas pada proses pembelajaran diperoleh data, sebanyak 5 orang guru terlambat masuk kelas kurang dari 10 menit, 7 orang guru terlambat masuk kelas 10 menit sampai dengan 15 menit, dan 11 orang guru terlambat masuk kelas lebih dari 15 menit.

Dari data diatas dapat ditarik kesimpulan bahwa tingkat keterlambatan guru masuk kelas lebih dari 15 menit pada proses kegiatan belajar mengajar masih tinggi yaitu 11 orang atau 47,83\%. Berdasarkan indikator yang telah ditetapkan bahwa keberhasilan tindakan ini adalah $75 \%$, atau bila $75 \%$ guru tidak terlambat lebih dari 10 menit. Pada siklus pertama ini guru yang tidak terlambat lebih dari 
10 menit baru 21,74\%, jadi peneliti berkesimpulan harus diadakan penelitian atau tindakan lagi pada siklus berikutnya atau siklus kedua.

\section{Refleksi}

Setelah selesai satu siklus maka diadakan refleksi mengenai kelemahan atau kekurangan dari pelaksanaan tindakan pada siklus pertama. Refleksi dilaksanakan bersama-sama kolaborator untuk menentukan tindakan perbaikan pada siklus berikutnya.

Dari hasil refleksi dapat diambil suatu kesimpulan bahwa perlu penerapan Reward dan Punishment yang lebih tegas lagi daripada siklus pertama.

\section{2) Siklus 2}

Siklus 2 terdiri atas beberapa tahap, sama seperti siklus 1 yaitu : (1) Perencanaan, (2) Pelaksanaan, (3) Pengamatan dan Evaluasi, dan (4) Refleksi.

\section{Perencanaan}

Dari hasil refleksi pada siklus pertama, peneliti merencanakan untuk melakukan tindakan Reward dan Punishment yang lebih tegas dibandingkan dengan siklus pertama. Peneliti merencanakan untuk mengumumkan hasil observasi mengenai tingkat keterlambatan guru masuk kelas dalam proses belajar mengajar, pada kegiatan upacara bendera hari Senin. Hal ini terlebih dahulu disosialisasikan kepada semua guru pada saat refleksi siklus pertama.

\section{Pelaksanaan}

Pelaksanaan penelitian tindakan sekolah pada siklus yang kedua ini dilaksanakan melalui beberapa kegiatan, antara lain :

a. Menyebarkan lembar pengamatan kepada setiap ketua kelas atau sekretaris kelas sebanyak 12 set, sesuai dengan banyaknya jumlah rombongan belajar di 
TK Mutiara Ibu Kota Jambi sebanyak 12 rombongan belajar. Dalam lembar pengamatan itu, telah dibuat daftar guru yang mengajar dikelas itu setiap jam dan diberi kolom jam masuk kelas serta jam keluar kelas. Lembar pengamatan dapat dilihat pada lampiran.

b. Berkoordinasi dengan petugas piket yang setiap hari terdiri dari 2 orang petugas, yaitu dari guru yang tidak mempunyai jam mengajar pada hari itudan satu orang dari tata usaha. Petugas piket akan mengedarkan daftar hadir guru dikelas yang telah dibuat agar dapat melihat tingkat kehadiran guru disetiap kelas dan disetiap pergantian jam pelajaran. Guru yang terlambat lebih dari 15 menit, dianggap tidak hadir dan diberi tanda silang. Daftar hadir guru dapat dilihat dalam lampiran.

c. Setelah selesai jam pelajaran, dilakukan rekapitulasi dari hasil pengamatan, baik dari guru piket, dari siswa maupun dari penulis. Kegiatan tersebut dilakukan terus setiap hari kepada setiap guru selama satu minggu (satu siklus) pada siklus kedua.

\section{Pengamatan dan Evaluasi}

Pengamatan atau observasi dilakukan oleh peneliti dengan menggunakan lembar observasi selama satu minggu (satu siklus), untuk semua guru yang berjumlah 23 orang. Selama pengamatan peneliti dibantu atau berkolaborasi dengan guru piket. Pengamatan oleh peneliti meliputi :

(a) Kehadiran guru dikelas

(b) Tingkat keterlambatan guru masuk kelas

(c) Waktu meninggalkan kelas setelah selesai pelajaran

Peneliti juga melakukan penilaian dari hasil lembar observasi yang dibagikan kepada pengurus kelas untuk mengamati kehadiran guru dikelas. Dari hasil pengamatan serta rekap dari tingkat kehadiran guru dikelas pada proses belajar mengajar pada siklus kedua dapat dilihat pada tabel berikut : 


\section{REKAPITULASI TINGKAT KETERLAMBATAN \\ GURU PADA KEHADIRAN DIKELAS \\ SIKLUS II}

\begin{tabular}{|l|l|l|}
\hline \multicolumn{3}{|l|}{ Waktu Keterlambatan/Jumlah/Prosentase } \\
\hline Kurang dari 10 menit & 10 menit s.d 15 menit & Lebih dari 15 menit \\
\hline 18 & 5 & 0 \\
\hline $78,26 \%$ & $21,74 \%$ & $0,00 \%$ \\
\hline
\end{tabular}

Dari hasil rekapitulasi tingkat keterlambatan guru dikelas pada proses pembelajaran diperoleh data, sebanyak 18 orang guru terlambat masuk kelas kurang dari 10 menit, 5 orang guru terlambat masuk kelas 10 menit sampai dengan 15 menit, dan tidak ada satu orangpun guru yang terlambat masuk kelas lebih dari 15 menit.

Dari hasil observasi pada siklus pertama dan siklus kedua dapat dilihat ada penurunan tingkat keterlambatan guru dikelas pada kegiatan belajar mengajar, atau terdapat peningkatan kehadiran guru dikelas.

\section{Refleksi}

Setelah selesai pelaksanaan tindakan pada siklus kedua maka diadakan refleksi mengenai kelemahan atau kekurangan dari pelaksanaan tindakan pada siklus kedua tersebut.

Dari hasil observasi dan data yang diperoleh, peneliti mengambil kesimpulan bahwa tindakan yang dilaksanakan pada siklus kedua dinyatakan berhasil, karena terdapat 78,26\% guru yang terlambat kurang dari 10 menit, atau melebihi target yang telah ditentukan sebesar $75 \%$. 


\section{E. KESIMPULAN DAN SARAN}

\section{Kesimpulan}

Berdasarkan analisis data, dari penelitian ini dapat ditarik kesimpulan bahwa penerapan Reward dan Punishment efektif untuk meningkatkan disiplin kehadiran guru dikelas pada kegiatan belajar mengajar. Data yang diperoleh menunjukan bahwa setelah diadakan penerapan tindakan berupa Reward dan Punishment, guru yang terlambat lebih dari 15 menit adalah 0 , dan guru yang terlambat kurang dari 10 menit sebanyak 18 orang guru. Penerapan Reward dan Punishment dapat meningkat disiplin guru dalam mengajar di kelas.

\section{Saran}

Karena adanya pengaruh positif Penerapan Reward dan Punishment terhadap disiplin guru hadir didalam kelas pada kegiatan belajar mengajar, maka melalui kesempatan ini penulis mengajukan beberapa saran:

1. Semua Kepada Kepala Sekolah disarankan melakukan Penerapan Reward dan Punishment untuk meningkatkan disiplin guru hadir didalam kelas pada kegiatan belajar mengajar di sekolah.

2. Kepada semua guru dalam melaksanakan tugas untuk dapat meningkatkan disiplin dalam kehadiran dikelas sebagai bentuk pelayanan minimal kepada peserta didik disekolah.

\section{DAFTAR PUSTAKA}

Ahmad Tohardi, Pemahaman Praktis Manajemen Sumber Daya Manusia, Bandung: Universitas Tanjung Pura.

Anwar Prabu Mangkunegara, Perencanaan Dan Pengembangan Sumber Daya Manusia, Bandung: Rafika Aditama, 2003.

Abdus Salam, Manajemen Insani dalam Bisnis, Yogyakarta: Pustaka Pelajar, 2014.

Abu Ahmadi dan Uhbiyati, Ilmu Pendidikan, Jakarta: Rineka Cipta, 1991. 
Arifin dan Barnawi, Etika Profesi Kependidikan, Jogjakarta:Ar-Ruzz Media, 2012.

Andi Rasdiyanah, Pendidikan Agama Islam, Bandung: Lubuh Agung, 1995.

Asmiarsih, Pengaruh Pengawasan Terhadap Disiplin Kerja Pegawai Badan Kepegawaian Daerah Kabupaten Brebes, Semarang: Universitas Negeri Semarang, 2006.

Dimyati dan Mudjiono, Belajar dan Pembelajaran, Jakarta: PT. Rineka Cipta, 2000.

Edy Sutrisno, Manajemen Sumber Daya Manusia, Jakarta: Prenadamedia Group, 2016.

E. Mulyasa, Kurikulum Berbasis Sekolah, Bandung: Remaja Rosdakarya, 2002.

Henry Simamora, Manajemen Sumber Daya Manusia, Yogyakarta: STIE YKPN, 1997.

Keith Davis dan John W. Newstrom, Perilaku Dalam Organisasi, Jakarta: Erlangga, T.th.

Malayu S.P Hasibuan, Manajemen Dasar, Pengertian Dan Masalah, Jakarta: PT Gunung Agung, 1996.

Malayu S.P Hasibuan, Manajemen Sumber Daya Manusia, Edisi Revisi, Jakarta: Bumi Aksara, 2005.

Markum Singodimedjo, Manajemen Sumber Daya Manusia, Surabaya: SMMAS, 2000.

Sondang P. Siagian, Manajemen Sumber Daya Manusia, Jakarta: PT Bumi Aksara, 2008.

Rika Ariyani, Editor Jurnal Literasiologi. Literasi Kita Indonesia. STAI Syekh Maulana Qori. Merangin Bangko. 